\title{
重症頭部外傷を合併する下肢長管骨骨折に対する 早期骨接合は酸素化能の悪化を防ぐ
}

$\begin{array}{llllll}\text { 一柳 裕司 } & \text { 鮫島 } & \text { 志郎 } & \text { 大場 } & \text { 次郎 } & \text { 明石 浩嗣 } \\ \text { 大津谷耕一 } & \text { 林 } & \text { 靖之 } & \text { 甲斐 } & \text { 達朗 } & \end{array}$

\begin{abstract}
要旨 重症頭部外傷を合併する下肢長管骨骨折症例に対し，長期に直達牵引を行えば体位変換が 制限され，無気肺や肺炎などを合併し，酸素化能の悪化を生じる可能性が高くなる。そこで下肢 長管骨骨折の早期骨接合により酸素化能の悪化を防ぎ得るかどうかを検討した。1991年 4 月から 2007 年 3 月までの 16 年間に当センターに搬送され, 骨接合が施行された直達牽引を要する下肢 長管骨骨折症例は228例であった。そのうち頭部にのみ abbreviated injury scale（AIS）3以上の外 傷を合併し，胸部，腹部などにはAIS 3 以上の外傷を合併しなかった症例は 34 例であった。そこ から，受傷後 24 時間以降第 5 病日までに骨接合が施行された症例，第 5 病日に血液ガス検査がな されていなかった症例，低体温療法が施行された症例を除外した 18 例を対象とした。これらを 受傷後 24 時間以内に骨接合が施行された症例（早期手術群）と第 6 病日以降に骨接合が施行され た症例（後期手術群）に分け，両群間の第 1 病日と第 5 病日の $\mathrm{PaO}_{2} / \mathrm{FIO}_{2}$ ratio (P/F ratio)， および それぞれの群の第 1 病日と第 5 病日の $\mathrm{P} / \mathrm{F}$ ratio を比較検討した。早期手術群は 8 例, 後期手術群は 10例で, 年齢, injury severity score（ISS），頭部AIS，下肢AISに差はないと判断した。早期手術 群の第 1 病日の平均 $\mathrm{P} / \mathrm{F}$ ratio は $453.3 \pm 56.6 \mathrm{mmHg}$, 第 5 病日の平均 $\mathrm{P} / \mathrm{F}$ ratio は $405.9 \pm 52.7 \mathrm{mmHg}$ で あった。後期手術群の第 1 病日の平均 $\mathrm{P} / \mathrm{F}$ ratio は $408.4 \pm 71.9 \mathrm{mmHg}$, 第 5 病日の平均 $\mathrm{P} / \mathrm{F}$ ratio は $305.1 \pm 104.6 \mathrm{mmHg}$ であった。両群間の第 1 病日の $\mathrm{P} / \mathrm{F}$ ratioに有意差を認めなかったが, 第 5 病日 のP/F ratioでは有意差を認めた（p<0.05）。また，それぞれの群の第1病日と第5病日の P/F ratio の比較では，早期手術群では有意差を認めなかったが，後期手術群では有意差を認めた $(\mathrm{p}<0.05)$ 。 な㧍死亡例はなかった。以上より，重症頭部外傷を合併する下肢長管骨骨折に対する早期骨接合 は酸素化能の悪化を防ぐと考えられた。
\end{abstract}

(日救急医会誌. 2010; 21: 19-28)

キーワード : 大腿骨骨折, 脛骨骨折, 多発外傷, 呼吸機能, $\mathrm{PaO}_{2} / \mathrm{FIO}_{2}$

\section{はじめに}

重症頭部外傷を合併する下肢長管骨骨折症例で は，頭部外傷の治療が優先され，下肢長管骨骨折に 対する骨接合の時期が遅れがちになる。骨接合がな

Early fixation of lower-extremity long bone fractures in patients with severe head injury prevents progressive oxygenation deterioration 大阪府済生会千里病院千里救命救急センター

著者連絡先：干 565-0862 大阪府吹田市津雲台 1-1-6

原稿受理日：2009年 8 月 27 日（09-059）
されず，直達牽引が長引くと，自動運動または体位 変換の制限により，無気肺や肺炎などの合併から酸 素化能が悪化する可能性が高くなる。一方, 重症頭 部外傷では, 意識レベルの低下により臥床期間が長 くなり，直達牽引の有無にかかわらず，無気肺や肺 炎などの合併から酸素化能が悪化する可能性があ る。そこで実際に下肢長管骨骨折に対する早期手術 が, 酸素化能の悪化を防ぎうるかどうかを検討した ので報告する。 
Table 1. Comparison of age, ISS, head AIS, and lower-extremity AIS between groups.

\begin{tabular}{cccc}
\hline & EFF & LFF & p Value \\
\hline Age & $33.8 \pm 14.4$ & $41.7 \pm 19.2$ & 0.35 \\
\hline ISS & $32.1 \pm 4.8$ & $31.8 \pm 4.8$ & 0.89 \\
\hline $\begin{array}{c}\text { Head } \\
\text { AIS }\end{array}$ & $4.63 \pm 0.52$ & $4.60 \pm 0.52$ & 0.92 \\
\hline $\begin{array}{c}\text { Lower-extremity } \\
\text { AIS }\end{array}$ & 3.0 & 3.0 & 1 \\
\hline
\end{tabular}

EFF: early fracture fixation, LFF: late fracture fixation, ISS: injury severity score, AIS: abbreviated injury scale.

\section{対象と方法}

1991 年 4 月から 2007 年 3 月までの 16 年間に当セ ンターに搬送され，骨接合が施行された直達牵引を 要する下肢長管骨骨折症例は228例であった。その うち, 頭部にのみ abbreviated injury scale ${ }^{1)}$ (AIS) 3 以上の外傷を合併し, 胸部, 腹部などにはAIS 3 以 上の外傷を合併しなかった症例は 34 例であった。 そこから更に受傷後 24 時間以降第 5 病日までに骨接 合が施行された症例，第 5 病日に血液ガス検査がな されていなかった症例，低体温療法が施行された症 例を除外した18例を対象とした。

これらを受傷後 24 時間以内に骨接合を施行した 症例（以下，早期手術群と略す）と第 6 病日以降に 骨接合を施行した症例（以下，後期手術群と略す） に分け, 両群間の第 1 病日と第 5 病日の $\mathrm{PaO}_{2} / \mathrm{FIO}_{2}$ ratio (P/F ratio)，およびそれぞれの群の第 1 病日と 第 5 病日の $P / F$ ratio を比較検討した。血液ガス検査

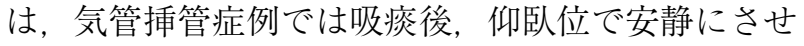
て約 10 分後に採血した。非挿管症例では, 酸素マ スクがしっかり装着された状態で，仰臥位のまま安 静にさせて約 10 分後に採血した。同一日に血液ガ ス検査が 2 回以上施行されている場合には, 最もよ いP/F ratioを適用した。統計学的検討はStudent's ttest, paired t-test, Fisher's exact test を用い, p $<0.05$ を有意差ありと判断した。平均值は平均值 \pm 標準 偏差で表した。

\section{結果}

早期手術群は 8 例, 後期手術群は 10 例であった。 両群間の年齢, injury severity score ${ }^{1)}$ (ISS), 頭部 AIS，下肢AISに差はないと判断した（Table 1, 2,3）。 両群の頭部外傷の傷病名をみると, 脳挫傷, 急性 硬膜外血腫, 急性硬膜下血腫, び漫性軸索損傷の単 独および合併であった。治療内容では，開頭手術を 施行されたものが早期手術群で 4 例, 後期手術群で 3例, barbiturate療法を施行されたものが早期手術 群で 2 例，後期手術群で 4 例，気管切開術を施行さ れたものが早期手術群で 2 例, 後期手術群で 3 例で あった（Table 2)。なお死亡例はなかった。

両群の骨接合が施行された下肢長管骨骨折部位を みると, 大腿骨骨折が早期手術群で 6 例 (7肢), 後 期手術群で 6 例 (7 肢), 脛骨骨折が早期手術群で 3 例 (4肢), 後期手術群が5例（5肢）であった。開 放骨折は早期手術群で 6 例 (9肢), 後期手術群で 5 例（5肢）であった。術式は，髄内釘が早期手術群 で6䇢所, 後期手術群で 3 箇所に施行され, 開放骨 折には non-reaming, 皮下骨折には reamingにて行わ れた。プレート固定が早期手術群で 1 箇所, 後期手 術群で 5 箇所に施行され, 創外固定が早期手術群で 4箇所, 後期手術群で4箇所に施行された。受傷か ら手術までの平均時間は, 早期手術群で $8.4 \pm 5.7$ 時 間，後期手術群で $8.4 \pm 3.3$ 日であった。症例 5 と症 例 7 の脛骨骨折は第6病日以降に骨接合が施行され ているが, 共に直達铱引を要しなかったため早期手 
Table 2. Distribution of head injuries in the two groups.

\begin{tabular}{|c|c|c|c|c|c|c|c|c|}
\hline $\begin{array}{l}\text { Case } \\
\text { No. }\end{array}$ & $\begin{array}{l}\text { Timing of } \\
\text { fixation }\end{array}$ & Age & Sex & ISS & $\begin{array}{l}\text { Head } \\
\text { AIS }\end{array}$ & Head injuries & $\begin{array}{l}\text { Operations } \\
\text { (Time from accident) }\end{array}$ & Special treatments \\
\hline 1 & $\mathrm{EFF}$ & 29 & M & 34 & 5 & $\begin{array}{l}\text { Acute epidural hematoma, } \\
\text { acute subdural hematoma }\end{array}$ & Craniotomy (4 hours) & \\
\hline 2 & $\mathrm{EFF}$ & 17 & M & 29 & 4 & $\begin{array}{l}\text { Brain contusion, acute epidural } \\
\text { hematoma, open depressed } \\
\text { vault fracture, basilar fracture }\end{array}$ & $\begin{array}{l}\text { Craniotomy, vaultplasty ( } 5 \\
\text { hours) }\end{array}$ & \\
\hline 3 & EFF & 15 & M & 38 & 5 & Diffuse axonal injury & & Tracheotomy \\
\hline 4 & $\mathrm{EFF}$ & 30 & M & 26 & 4 & $\begin{array}{l}\text { Brain contusion, acute epidural } \\
\text { hematoma, acute subdural he- } \\
\text { matoma }\end{array}$ & $\begin{array}{l}\text { Insertion of ICP sensor ( } 6 \\
\text { hours) } \\
\text { Craniotomy, decompression } \\
\text { ( } 23 \text { hours) }\end{array}$ & Barbiturate therapy \\
\hline 5 & $\mathrm{EFF}$ & 31 & M & 35 & 5 & $\begin{array}{l}\text { Diffuse axonal injury, brain } \\
\text { contusion, traumatic subarach- } \\
\text { noid hemorrhage }\end{array}$ & & \\
\hline 6 & $\mathrm{EFF}$ & 54 & $\mathrm{M}$ & 35 & 5 & $\begin{array}{l}\text { Diffuse axonal injury, traumat- } \\
\text { ic intracerebral hemorrhage }\end{array}$ & & \\
\hline 7 & $\mathrm{EFF}$ & 44 & M & 25 & 4 & Brain contusion & & \\
\hline 8 & $\mathrm{EFF}$ & 50 & M & 35 & 5 & $\begin{array}{l}\text { Brain contusion, acute subdur- } \\
\text { al hematoma, } \\
\text { traumatic subarachnoid hemor- } \\
\text { rhage }\end{array}$ & $\begin{array}{l}\text { Fenestration ( } 2 \text { hours) } \\
\text { Craniotomy, decompression } \\
\text { (21 hours) }\end{array}$ & $\begin{array}{l}\text { Barbiturate therapy, } \\
\text { tracheotomy }\end{array}$ \\
\hline 9 & LFF & 37 & M & 35 & 5 & Diffuse axonal injury & & \\
\hline 10 & LFF & 26 & M & 26 & 4 & Brain contusion & & \\
\hline 11 & LFF & 25 & M & 38 & 5 & $\begin{array}{l}\text { Brain contusion, acute epidural } \\
\text { hemorrhage }\end{array}$ & Craniotomy (10 hours) & $\begin{array}{l}\text { Barbiturate therapy, } \\
\text { tracheotomy }\end{array}$ \\
\hline 12 & LFF & 59 & $\mathrm{~F}$ & 34 & 5 & $\begin{array}{l}\text { Brain contusion, acute epidural } \\
\text { hematoma, traumatic suba- } \\
\text { rachnoid hemorrhage }\end{array}$ & Craniotomy (4 hours) & \\
\hline 13 & LFF & 20 & $\mathrm{M}$ & 35 & 5 & $\begin{array}{l}\text { Diffuse axonal injury, brain } \\
\text { contusion, acute epidural hem- } \\
\text { orrhage }\end{array}$ & Craniotomy (19 hours) & $\begin{array}{l}\text { Barbiturate therapy, } \\
\text { tracheotomy }\end{array}$ \\
\hline 14 & LFF & 59 & M & 35 & 5 & $\begin{array}{l}\text { Diffuse axonal injury, traumat- } \\
\text { ic subarachnoid hemorrhage }\end{array}$ & & \\
\hline 15 & LFF & 49 & $\mathrm{~F}$ & 26 & 4 & $\begin{array}{l}\text { Brain contusion, acute subdur- } \\
\text { al hematoma, }\end{array}$ & & Barbiturate therapy \\
\hline 16 & LFF & 22 & $\mathrm{~F}$ & 25 & 4 & $\begin{array}{l}\text { Brain contusion, acute subdur- } \\
\text { al hematoma, }\end{array}$ & & Barbiturate therapy \\
\hline 17 & LFF & 77 & M & 35 & 5 & Diffuse axonal injury & & Tracheotomy \\
\hline 18 & LFF & 43 & M & 29 & 4 & Brain contusion & & \\
\hline
\end{tabular}

ISS: injury severity score, AIS: abbreviated injury scale, EFF: early fracture fixation, LFF: late fracture fixation, ICP: intracranial pressure

術群とした。逆に, 症例 9 の脛骨骨折は受傷から 4 時間後に骨接合が施行されているが，大腿骨骨折の 骨接合が受傷から 6 日後に施行されているため後期 手術群とした（Table 3)。
両群の他の外傷を Table 4 に示した。四肢・頭部 以外にはAIS 3 以上の外傷はなかった。両群間の第 1 病日と第 5 病日の $\mathrm{P} / \mathrm{F}$ ratio を比較すると, 早期手 術群の第 1 病日の平均 $\mathrm{P} / \mathrm{F}$ ratio は $453.3 \pm 56.6 \mathrm{mmHg}$, 
Table 3. Distribution of lower-extremity long bone fractures in the two groups.

\begin{tabular}{|c|c|c|c|c|c|c|c|c|c|}
\hline $\begin{array}{l}\text { Case } \\
\text { No. }\end{array}$ & $\begin{array}{l}\text { Timing of } \\
\text { fixation }\end{array}$ & Age & Sex & ISS & $\begin{array}{l}\text { Lower- } \\
\text { extremity } \\
\text { AIS }\end{array}$ & $\begin{array}{l}\text { Fixed lower-extremity long } \\
\text { bone fractures (Gustilo clas- } \\
\text { sification) }\end{array}$ & $\begin{array}{l}\text { Fixation } \\
\text { methods }\end{array}$ & $\begin{array}{l}\text { Time from } \\
\text { accident }\end{array}$ & $\begin{array}{l}\text { Additional fixed } \\
\text { fractures }\end{array}$ \\
\hline 1 & $\mathrm{EFF}$ & 29 & M & 34 & 3 & Rt. femur shaft fracture & Plate & 8 hours & \\
\hline 2 & $\mathrm{EFF}$ & 17 & M & 29 & 3 & $\begin{array}{l}\text { Bil. open femur shaft frac- } \\
\text { ture (Gustilo I) }\end{array}$ & $\begin{array}{l}\text { Bil. IMN } \\
\text { (non-reaming) }\end{array}$ & 9 hours & $\begin{array}{l}\text { Bil. multiple meta- } \\
\text { carpal fractures }\end{array}$ \\
\hline 3 & $\mathrm{EFF}$ & 15 & M & 38 & 3 & $\begin{array}{l}\text { Lt. open femur shaft fracture } \\
\text { (Gustilo IIIA) }\end{array}$ & $\begin{array}{l}\text { IMN } \\
\text { (non-reaming) }\end{array}$ & 6 hours & \\
\hline 4 & $\mathrm{EFF}$ & 30 & M & 26 & 3 & $\begin{array}{l}\text { Rt. open femur condylar } \\
\text { fracture (Gustilo IIIA) }\end{array}$ & EF and screw & 6 hours & \\
\hline \multirow[t]{2}{*}{5} & $\mathrm{EFF}$ & 31 & M & 35 & 3 & $\begin{array}{l}\text { Rt. open femur shaft fracture } \\
\text { (Gustilo II) }\end{array}$ & $\begin{array}{l}\text { IMN } \\
\text { (non-reaming) }\end{array}$ & 6 hours & $\begin{array}{l}\text { 5th cervical frac- } \\
\text { ture (no palsy) }\end{array}$ \\
\hline & & & & & & $\begin{array}{l}\text { Rt. open tibia shaft fracture } \\
\text { (Gustilo I, no traction) }\end{array}$ & IMN & 11 days & Rt. patella fracture \\
\hline 6 & $\mathrm{EFF}$ & 54 & M & 35 & 3 & $\begin{array}{l}\text { Lt. femur intertrochanteric } \\
\text { and open shaft fractures } \\
\text { (Gustilo II) }\end{array}$ & $\begin{array}{l}\text { IMN } \\
\text { (non-reaming) }\end{array}$ & 5 hours & $\begin{array}{l}\text { Lt. radius fracture, } \\
\text { lt. ulna fracture }\end{array}$ \\
\hline \multirow[t]{2}{*}{7} & $\mathrm{EFF}$ & 44 & M & 25 & 3 & $\begin{array}{l}\text { Rt. open tibia shaft fracture } \\
\text { (Gustilo IIIB) }\end{array}$ & $\mathrm{EF}$ & 4 hours & \\
\hline & & & & & & $\begin{array}{l}\text { Lt. open tibia shaft fracture } \\
\text { (Gustilo II, no traction) }\end{array}$ & $\mathrm{EF}$ & 23 days & \\
\hline 8 & $\mathrm{EFF}$ & 50 & M & 35 & 3 & $\begin{array}{l}\text { Rt. tibia shaft fracture, Rt. } \\
\text { fibula shaft fracture }\end{array}$ & EF, pinning & 22 hours & \\
\hline \multirow[t]{2}{*}{9} & LFF & 37 & M & 35 & 3 & $\begin{array}{l}\text { Lt. open tibia shaft fracture } \\
\text { (Gustilo I) }\end{array}$ & Plate & 4 hours & $\begin{array}{l}\text { Lt. open patella } \\
\text { fracture }\end{array}$ \\
\hline & & & & & & $\begin{array}{l}\text { Lt. femur neck and shaft } \\
\text { fracture }\end{array}$ & $\begin{array}{l}\text { IMN } \\
\text { (reaming) }\end{array}$ & 6 days & $\begin{array}{l}\text { Lt. radius fracture, } \\
\text { lt. ulna fracture }\end{array}$ \\
\hline 10 & LFF & 26 & M & 26 & 3 & Rt. femur shaft fracture & Plate & 5 days & $\begin{array}{l}\text { Rt. metatarsal frac- } \\
\text { ture }\end{array}$ \\
\hline 11 & $\mathrm{LFF}$ & 25 & M & 38 & 3 & $\begin{array}{l}\text { Lt. open femur shaft fracture } \\
\text { (Gustilo II) }\end{array}$ & Plate & 12 days & \\
\hline 12 & $\mathrm{LFF}$ & 59 & $\mathrm{~F}$ & 34 & 3 & Lt. femur shaft fracture & $\begin{array}{l}\text { IMN } \\
\text { (reaming) }\end{array}$ & 10 days & \\
\hline 13 & LFF & 20 & M & 35 & 3 & Bil. femur shaft fracture & Bil. EF & 5 days & \\
\hline 14 & LFF & 59 & M & 35 & 3 & Rt. femur shaft fracture & $\begin{array}{l}\text { IMN (ream- } \\
\text { ing) }\end{array}$ & 13 days & \\
\hline 15 & LFF & 49 & $\mathrm{~F}$ & 26 & 3 & $\begin{array}{l}\text { Lt. open tibia shaft fracture } \\
\text { (Gustilo II) }\end{array}$ & Plate & 12 days & \\
\hline 16 & LFF & 22 & $\mathrm{~F}$ & 25 & 3 & $\begin{array}{l}\text { Rt. open tibia shaft fracture } \\
\text { (Gustilo II) }\end{array}$ & $\mathrm{EF}$ & 10 days & \\
\hline 17 & LFF & 77 & M & 35 & 3 & Rt. tibia shaft fracture & Plate & 5 days & \\
\hline 18 & $\mathrm{LFF}$ & 43 & M & 29 & 3 & $\begin{array}{l}\text { Rt. open tibia shaft fracture } \\
\text { (Gustilo II) }\end{array}$ & $\mathrm{EF}$ & 6 days & \\
\hline
\end{tabular}

EFF: early fracture fixation, LFF: late fracture fixation, IMN: intramedullary nailing, EF: external fixation, OR: operating room 
Table 4. Distribution of additional injuries in the two groups.

\begin{tabular}{ccccl}
\hline $\begin{array}{c}\text { Case } \\
\text { No. }\end{array}$ & $\begin{array}{c}\text { Timing of } \\
\text { fixation }\end{array}$ & Age & Sex & Additional injuries \\
\hline 1 & EFF & 29 & M & \\
2 & EFF & 17 & M & Facial bone fracture (AIS 2), rt. ulna fracture \\
3 & EFF & 15 & M & Liver contusion (AIS 2) \\
4 & EFF & 30 & M & \\
5 & EFF & 31 & M & Lt. clavicle fracture, rt. toe fracture \\
6 & EFF & 54 & M & Rt. ischium fracture, lt. multiple metatarsal fracture \\
7 & EFF & 44 & M & Lt. multiple metatarsal fractures, Rt. fibula fracture \\
8 & EFF & 50 & M & Lt. scapula fracture, lt. fibula fracture \\
\hline 9 & LFF & 37 & M & Lt. multiple metatarsal fractures, Lt. multiple toe fractures \\
10 & LFF & 26 & M & \\
11 & LFF & 25 & M & Facial bone fracture (AIS 2) \\
12 & LFF & 59 & F & Lt. acetabulum fracture, lt. open patella fracture \\
13 & LFF & 20 & M & Lt. acromioclavicular joint dislocation \\
14 & LFF & 59 & M & Lt. open tibia fracture (Gustilo IIIC), lt. open fibula fracture (Gustilo IIIC) \\
15 & LFF & 49 & F & Lt. fibula fracture \\
16 & LFF & 22 & F & Rt. acetabulum fracture, lt. pubic fracture, rt. fibula fracture \\
17 & LFF & 77 & M & Rt. fibula fracture \\
18 & LFF & 43 & M & Facial bone fracture (AIS 2), lt. clavicle fracture, rt. fibula fracture \\
\hline & & & &
\end{tabular}

EFF: early fracture fixation, LFF: late fracture fixation, AIS: abbreviated injury score

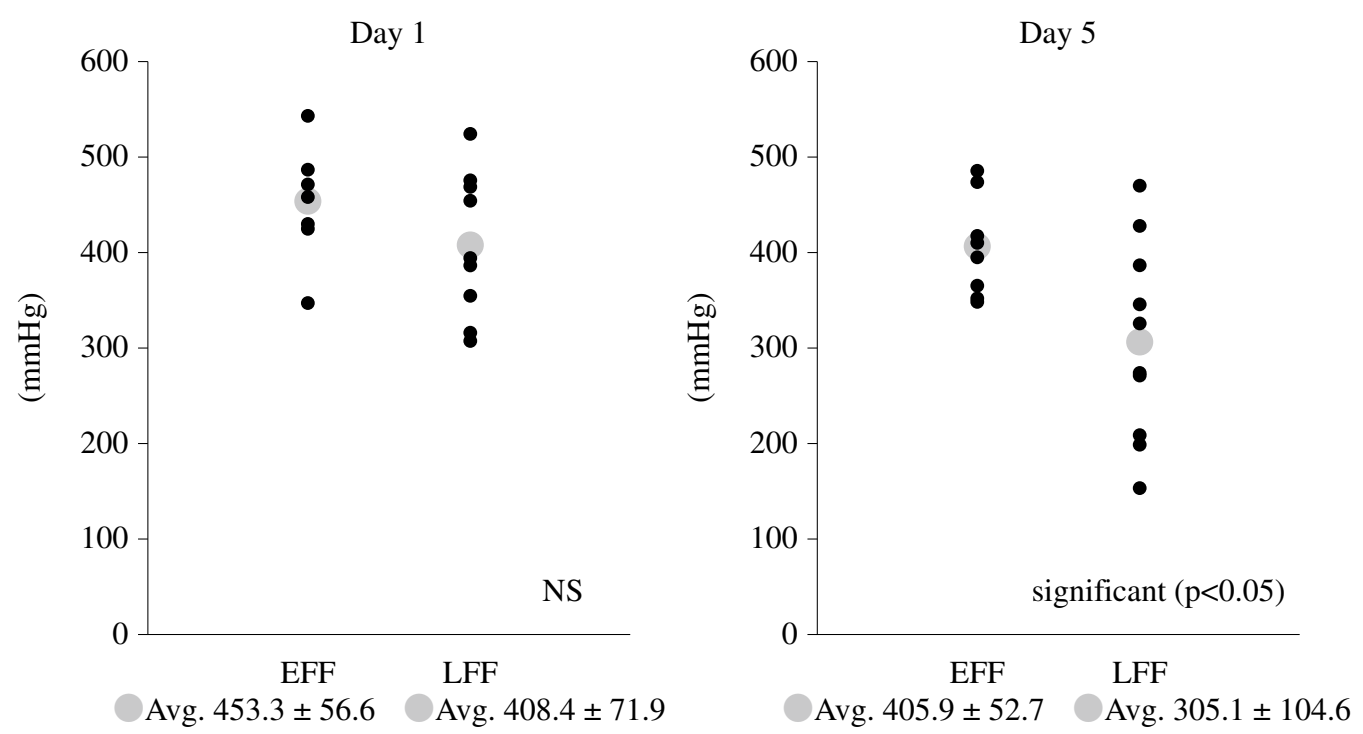

Fig. 1. Comparison of $\mathrm{PaO}_{2} / \mathrm{FIO}_{2}$ ratio at days 1 and 5 between groups.

Although the difference in $\mathrm{P} / \mathrm{F}$ ratio between groups at day 1 was not statistically significant, the difference in $\mathrm{P} / \mathrm{F}$ ratio at day 5 was statistically significant $(\mathrm{p}<0.05)$.

EFF: early fracture fixation, LFF: late fracture fixation, NS: not significant

後期手術群では $408.4 \pm 71.9 \mathrm{mmHg}$ 。早期手術群の第 5 病日の平均 $\mathrm{P} / \mathrm{F}$ ratio は $405.9 \pm 52.7 \mathrm{mmHg}$, 後期手 術群では305.1 $\pm 104.6 \mathrm{mmHg}$ で両群間の第1病日の
$\mathrm{P} / \mathrm{F}$ ratioに有意差を認めなかったが，第5 病日の $\mathrm{P} / \mathrm{F}$ ratioでは有意差を認めた（Fig. 1)。

それぞれの群の第 1 病日と第 5 病日の P/F ratio 

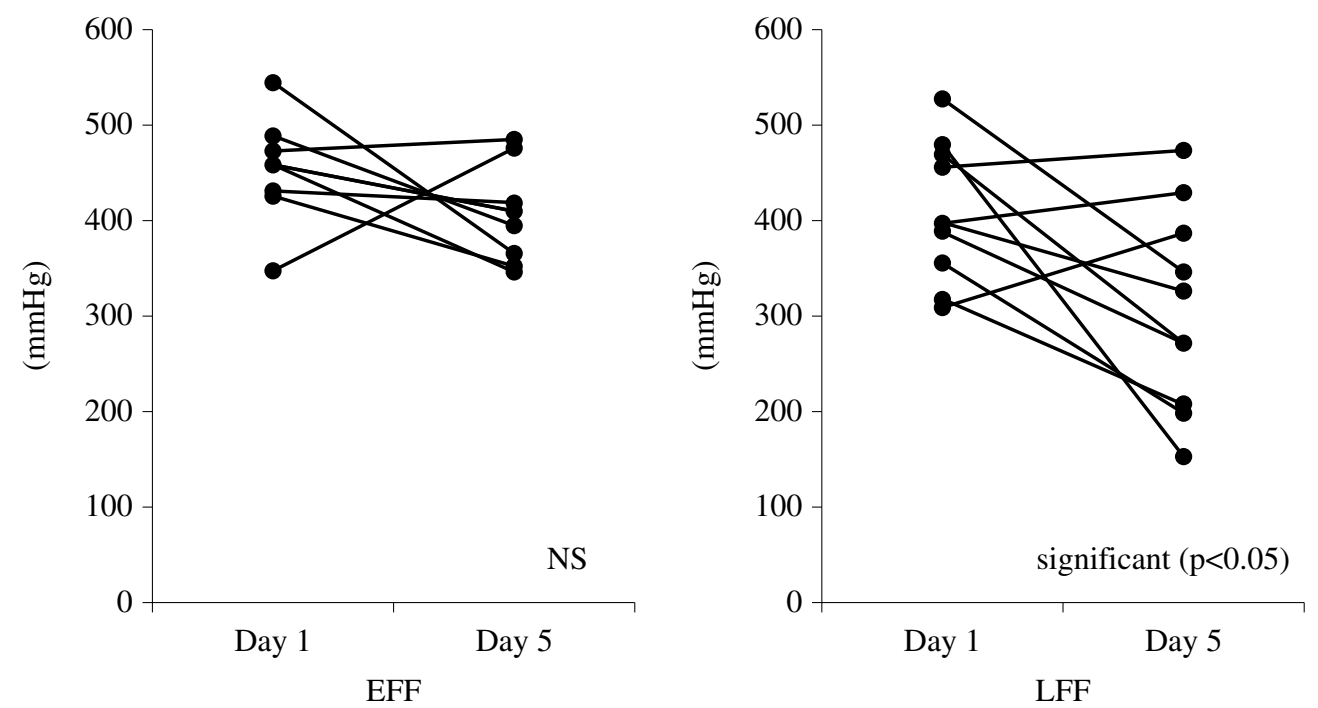

Fig. 2. Comparison of $\mathrm{PaO}_{2} / \mathrm{FIO}_{2}$ ratios at days 1 and 5 within each group. Although there was no significant difference in P/F ratio at days 1 and 5 in the EFF group, the difference in $\mathrm{P} / \mathrm{F}$ ratio at days 1 and 5 in the LFF group was statistically significant $(\mathrm{p}<0.05)$. EFF: early fracture fixation, LFF: late fracture fixation, NS: not significant
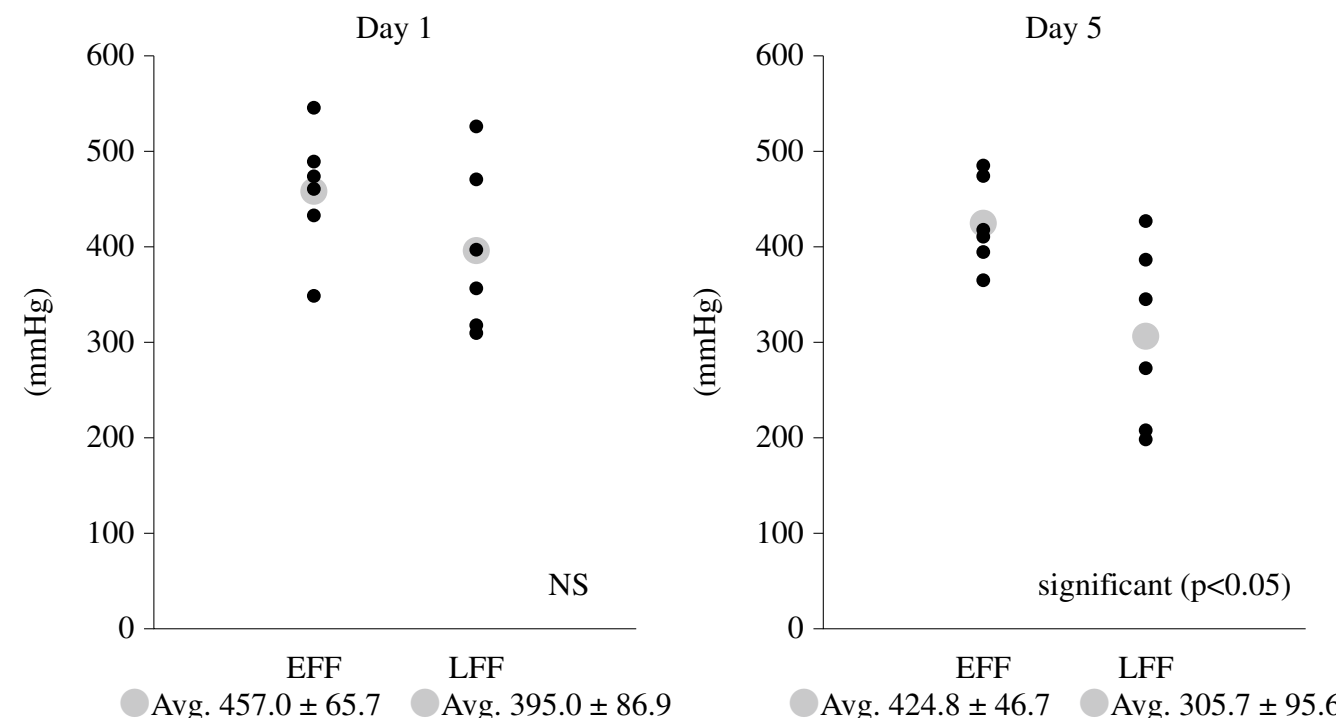

Fig. 3. Comparison of $\mathrm{PaO}_{2} / \mathrm{FIO}_{2}$ ratio at days 1 and 5 between groups excluding barbiturate therapy cases. Although the difference in $\mathrm{P} / \mathrm{F}$ ratio between groups excluding barbiturate therapy cases at day 1 was not statistically significant, the difference in $\mathrm{P} / \mathrm{F}$ ratio at day 5 was statistically significant $(\mathrm{p}<0.05)$.

EFF: early fracture fixation, LFF: late fracture fixation, NS: not significant

比較すると，早期手術群では，第 1 病日と第 5 病日 の $\mathrm{P} / \mathrm{F}$ ratioに有意差を認めなかったが, 後期手術群 では有意差を認めた（Fig. 2)。

また，barbiturate療法を施行した症例を除く両群間 の第 1 病日と第 5 病日の $\mathrm{P} / \mathrm{F}$ ratio を比較しても, 早期 手術群の第1病日の平均 $\mathrm{P} / \mathrm{F}$ ratioは $457.0 \pm 65.7 \mathrm{mmHg}$,
後期手術群では $395.0 \pm 86.9 \mathrm{mmHg}$ 。早期手術群の第 5 病日の平均 $\mathrm{P} / \mathrm{F}$ ratio は $424.8 \pm 46.7 \mathrm{mmHg}$, 後期手術群 では305.7 $\pm 95.6 \mathrm{mmHg}$ で両群間の第 1 病日の $\mathrm{P} / \mathrm{F}$ ratio に有意差を認めなかったが，第5病日の $\mathrm{P} / \mathrm{F}$ ratioでは 有意差を認めた（Fig.3）。 


\section{考察}

重症頭部外傷を合併する下肢長管骨骨折症例は, 頭部外傷の治療が優先されるため, 直接的に命に関 わらない可能性の高い下肢長管骨骨折の手術は後回 しにされてきた。しかし, 長期に直達牽引を行えば, 自動運動または体位変換の制限により, 無気肺や肺 炎などの合併から酸素化能の悪化を生じる可能性が ある。また，救命はできたとしても機能予後は悪く なる可能性がある。そのため今日では, 重症頭部外 傷を合併していても，下肢長管骨骨折に対し積極的 に早期手術がなされる傾向となってきた ${ }^{2-9)}$ 。そこ で，実際に重症頭部外傷を合併する下肢長管骨骨折 に対する早期骨接合が酸素化能の悪化を防ぐかどう かを検討した。低体温療法が施行された症例は直達 率引の有無にかかわらず，無気肺や肺炎などを合併 しやすいため除外した。早期手術群と後期手術群を 連続する時間で分けると, 比較的短時間の差で両群 に分かれてしまい比較する症例が出てくること，ま た現在我々は遅くとも5日以内には骨接合をすべき と考えていることより早期手術群を受傷後 24 時間 以内, 後期手術群を第 6 病日以降とした。原則とし て，1997年3月以前の骨接合はすべて待期的にされ， 1997 年 4 月以降の開放骨折は緊急手術がなされた。 Barbiturate療法を施行されたものが早期手術群で2 例, 後期手術群で 4 例あり, 後期手術群の方が多い が，これらを除いた早期手術群 6 例と後期手術群 6 例とを比較しても，第 5 病日の $\mathrm{P} / \mathrm{F}$ ratio で有意差を 認めた。

重症頭部外傷を合併する下肢長管骨骨折に対する 適切な手術時期について，いまだに結論は出ていな い。早期骨接合により, 脂肪塞栓症候群, 肺動脈血 栓塞栓症, 肺炎, 無気肺などの合併症が減る, 骨折 部の止血が得られる，骨折部の整復が容易である， 早期機能回復が得られる, 疼痛が緩和される, 看護 が容易になるなど，利点が多いのは明らかであ る2-8)。しかし，重症頭部外傷を合併しているのが問 題である。Kotwica ${ }^{2)} は$ ，重症頭部外傷を合併する
骨盤骨折または下肢長管骨骨折症例のうち，受傷後 12 時間以内に骨接合を施行した群と受傷後 4 日後か ら10日後に骨接合を施行した群を比較し，前者の 51 例に脂肪塞栓症候群による死亡例はなかったのに 対し, 後者の 49 例に脂肪塞栓症候群による死亡が 3 例あったと報告している。Hofman ら ${ }^{3)}$ は，来院時の Glasgow Coma Scale（GCS）が7以下の重症頭部外傷 を有する症例のうち，合併する脊椎骨折，骨盤骨折 または下肢長管骨骨折に対し受傷後 24 時間以内に骨 接合を施行した群と，24時間以内に骨接合をしな かったまたは骨折を合併しなかった群を比較し，前 者の方がISSが高いにもかかわらず死亡率は低く， Glasgow Outcome Scale もよかったと報告している。 他にも早期手術を推奨する文献 4-6, 9-11) はみられるが, その理由は必ずしも早期手術が呼吸器合併症を減ら すというわけではなかった。

一方 Martens ら ${ }^{12)}$ は，重症頭部外傷を合併する骨 折の早期骨接合群と後期骨接合群の脳神経学的悪化 の有無を比較し，早期骨接合群 13 例中 5 例に脳神経 学的悪化を認めたのに対し, 後期骨接合群の9例に は脳神経学的悪化を認めなかったと報告している。 Jaicks ら ${ }^{13)}$ は, ISS が12 以上の多発外傷患者のうち, 頭部AIS が 2 以上かつ骨接合を要する四肢AIS が 2 以上の症例のなかで, 来院後 24 時間以内の早期骨 接合群と来院後 24 時間以降の後期骨接合群を比較 した。早期骨接合群は術中, 来院後 24 時間および 来院後 48 時間の輸液量, 輸血量が多かった。また 二次的脳損傷の原因となる術中の低血圧や低酸素は 早期骨接合群で多くみられた。そして, 後期骨接合 群は全例, 意識が清明になって退院したが, 早期骨 接合群では，19例中 3 例は意識が清明にならないま ま退院したと報告している。他にも後期骨接合を推 奨する文献 ${ }^{14-16)}$ はみられるが，いずれも呼吸器合併 症については述べられていない。

更にVelmahos ら ${ }^{17)}$ は，頭部AIS が3以上で，来院 時の GCS が 8 以下の重症頭部外傷を合併する四肢骨 折症例を, 来院から 24 時間以内に骨接合を施行し た群と来院から 24 時間以降に骨接合を施行した群 
を比較した。両群で骨接合術中, 術後の低血圧, 低 酸素の頻度は同等で, 合併症の発症率や死亡率, 退 院時のGCSに差はなかったと報告している。Scalea ら ${ }^{18)}$ は，頭部外傷を合併する骨盤骨折あるいは下 肢骨折症例のうち, 来院後 24 時間以内に骨接合を した群と来院後 24 時間以降に骨接合を施行した群 を比較した。両群で肺炎や acute respiratory distress syndrome（ARDS）の発症率, 脳神経学的合併症の 発症率, 死亡率, 退院時の GCS に差はなかったと 報告している。これらのように骨接合時期と合併症 や死亡率とは関係ないとする文献 ${ }^{19-21)}$ みられる。

いくつかの文献を集め, 内容を吟味, 整理し, そ の結果を報告している文献もあるが, Giannoudis ら 22)は，頭部外傷を合併する骨折に対する定まっ た治療指針はなく，早期骨接合がよりよい予後をも たらす傾向にあったが, 症例に応じて治療方針を立 てるべきと述べている。Eastern association for the surgery of traumaのガイドライン 23) では, 重症頭部 外傷を合併する長管骨骨折の早期骨接合が, 予後を 悪くするという証拠はない。長管骨骨折の手術時期 は, 患者の臨床状態に応じて個別に決定されるべき となっている。

このように文献的には，早期手術を推奨するも の, 後期手術を推奨するもの, 手術時期は関係ない とするものがあり, 骨接合時期について結論は出て いない。

ところで，これらの文献には研究のデザインに問 題があると思われるものが多数みられる。重症頭部 外傷の合併を対象症例としていても, 他に重症の胸 部外傷や腹部外傷なども合併している症例を含めて しまっている場合が多い。そうなると頭部以外の外 傷が, 合併症や脳神経学的機能予後, 死亡率に関与 した可能性が出てくる。また, 重症頭部外傷の定義 も様々で重症とは思えない頭部外傷も対象症例に含 めている場合がある。更に呼吸機能については, 脂 肪塞栓症候群, ARDS, 肺炎, 無気肺, 呼吸不全な どの合併症の発症率で評価している場合がほとんど であるが，これもそれぞれの定義が問題であり，そ
こにバイアスがかかる可能性がある。

本研究では, 四肢以外に頭部にのみAIS 3 以上の 外傷を合併し, 胸部や腹部などにはAIS 3 以上の外 傷を合併しない症例を対象とした。また呼吸機能の 評価は合併症の有無ではなく $\mathrm{P} / \mathrm{F}$ ratio 用いた。重 症頭部外傷を合併する下肢長管骨骨折等の骨接合時 期について P/F ratioを用いて比較した文献はみつけ られなかった。ARDSや呼吸不全などの肺合併症の 診断基準の一つとして P/F ratioを用いている文 献5,9,17)をいくつかみつけたのみであった。

しかし，頭部にのみAIS 3 以上の外傷を合併する 症例を対象とすると症例数はかなり少なくなる。高 エネルギー外傷では, 胸部や腹部などにも重症外傷 を合併している可能性が高い。更に P/F ratio を算出 するには血液ガス検査が必要であり, その検査が毎 日施行されているわけではない。当センターでは重 症外傷全例に対し, 来院日に少なくとも 1 回の血液 ガス検査がなされているが，第5病日には全例に血 液ガス検査がなされているわけではなく, 早期骨接 合が施行され，すでに安定している症例では，第 5 病日に血液ガス検査がなされていないことも多い。 そのため本研究の症例数は非常に少なくなったが, 有意差を認めることができた。

今回の研究から, 重症頭部外傷を合併する下肢長 管骨骨折に対する早期骨接合が酸素化能の悪化を防 ぐことがわかった。現在，当センターでは重症頭部 外傷を合併していても，下肢長管骨骨折に対し積極 的に早期手術を施行している。とくに開放骨折で は, 可能な限り Golden hour内に施行している。 1997 年 4 月以降, 重症頭部外傷を合併する下肢長管 骨開放骨折症例 (AIS 3 以上の胸部または腹部外傷 の合併も含む）37例中 33 例に緊急骨接合を施行し, 死亡例はなかった。緊急骨接合をしなかった4例は, 来院時より脳圧が高かった症例や Golden hour内に 循環動態が安定しなかった症例であった。頭部外傷 の重症度の正確な評価，骨折に対する術式の選択お よび適切な麻酔管理にて早期手術は安全に施行でき る。しかし, 重症頭部外傷のなかでも, 脳圧の高い 
症例に対する早期骨接合は，やはりリスクが高く， その適応基準の作成が今後の課題となろう。

\section{結論 \\ 重症頭部外傷を合併する下肢長管骨骨折に対する 早期骨接合は，酸素化能の悪化を防ぐ。}

\section{文献}

1) Association for the Advancement of Automotive Medicine: Abbreviated Injury Scale (AIS), 1990 Revised Version: Update98.

2) Kotwica Z, Balcewicz L, Jagodzinski Z: Head injuries coexistent with pelvic or lower extremity fractures--early or delayed osteosynthesis. Acta Neurochir (Wien). 1990; 102: 19-21.

3) Hofman PA, Goris RJ: Timing of osteosynthesis of major fractures in patients with severe brain injuries. J Trauma. 1991; 31: 261-3.

4) Bone LB, McNamara K, Shine B, et al: Mortality in multiple trauma patients with fractures. J Trauma. 1994; 37: 262-5.

5) Starr AJ, Hunt JL, Chason DP, et al: Treatment of femur fracture with associated head injury. J Orthop Trauma. 1998; 12: 38-45.

6) Brundage SI, McGhan R, Jurkovich GJ, et al: Timing of femur fracture fixation: effect on outcome in patients with thoracic and head injuries. J Trauma. 2002; 52: 299-307.

7) Bone LB, Johnson KD, Weigelt J, et al: Early versus delayed stabilization of femoral fractures. A prospective randomized study. J Bone Joint Surg Am. 1989; 71: 336-40.

8) van Os JP, Roumen RM, Schoots FJ, et al: Is early osteosynthesis safe in multiple trauma patients with severe thoracic trauma and pulmonary contusion? J Trauma. 1994; 36: 495-8.

9) Poole GV, Miller JD, Agnew SG, et al: Lower extremity fracture fixation in head-injured patients. J Trauma. 1992; 32: 654-9.

10) McKee MD, Schemitsch EH, Vincent LO, et al: The effect of a femoral fracture on concomitant closed head injury in patients with multiple injuries. J Trauma. 1997; 42:1041-5.
11) Bhandari M, Guyatt GH, Khera V, et al: Operative management of lower extremity fractures in patients with head injuries. Clin Orthop Relat Res. 2003; 407: 187-98.

12) Martens F, Ectors P: Priorities in the management of polytraumatised patients with head injury: partially resolved problems. Acta Neurochir (Wien). 1988; 94: 70-3.

13) Jaicks RR, Cohn SM, Moller BA: Early fracture fixation may be deleterious after head injury. J Trauma. 1997; 42: 1-5.

14) Townsend RN, Lheureau T, Protech J, et al: Timing fracture repair in patients with severe brain injury (Glasgow Coma Scale score <9). J Trauma. 1998; 44: 977-83.

15) Sanker P, Frowein RA, Richard KE: Multiple injuries: coma and fractures of the extremities. Neurosurg Rev. 1989; 12 suppl 1: 51-4.

16) Fakhry SM, Rutledge R, Dahners LE, et al: Incidence, management, and outcome of femoral shaft fracture: a statewide population-based analysis of 2805 adult patients in a rural state. J Trauma. 1994; 37: 255-60.

17) Velmahos GC, Arroyo H, Ramicone E, et al: Timing of fracture fixation in blunt trauma patients with severe head injuries. Am J Surg. 1998; 176: 324-30.

18) Scalea TM, Scott JD, Brumback RJ, et al: Early fracture fixation may be, "just fine" after head injury: no difference in central nervous system outcomes. J Trauma. 1999; 46: 839-46.

19) Reynolds MA, Richardson JD, Spain DA, et al: Is the timing of fracture fixation important for the patient with multiple trauma? Ann Surg. 1995; 222: 470-81.

20) Malisano LP, Hunter GA: The management of long bone fractures in the head-injured polytrauma patient. J Orthop Trauma. 1994; 8: 1-5.

21) Kalb DC, Ney AL, Rodriguez JL, et al: Assessment of the relationship between timing of fixation of the fracture and secondary brain injury in patients with multiple trauma. Surgery. 1998; 124: 739-45.

22) Giannoudis PV, Veysi VT, Pape HC, et al: When should we operate on major fractures in patients with severe head injuries? Am J Surg. 2002; 183: 261-7.

23) Dunham CM, Bosse MJ, Clancy TV, et al: Practice management guidelines for the optimal timing of long bone fracture stabilization in polytrauma patients. J Trauma. 2000; 50: 95867. 


\section{ABSTRACT \\ Early fixation of lower-extremity long bone fractures in patients with severe head injury prevents progressive oxygenation deterioration

\author{
Hiroshi Ichiyanagi, Shirou Sameshima, Jirou Ooba, Kouji Akashi \\ Kouichi Ootsuya, Yasuyuki Hayashi, Tatsurou Kai
} \\ Senri Critical Care Medical Center, Saiseikai Senri Hospital, Osaka Prefecture}

If patients with lower-extremity long bone fractures and severe head injury are treated with lower-extremity traction, they must remain in the supine position for long periods, and their oxygenation may worsen due to atelectasis, pneumonia, or other conditions. We studied whether early fixation of lower-extremity long bone fractures in patients with severe head injury prevents progressive oxygenation deterioration. The study comprised 228 patients requiring traction for lower-extremity long bone fracture fixation who were admitted to our center from April, 1991 through March, 2007. Of these patients, 34 had severe head injury (Abbreviated Injury Scale (AIS) $\geq 3$ ) but did not suffer additional severe injury (AIS $\geq 3$ ) to the thorax or abdomen. Patients who underwent fracture fixation from 24 hours to 5 days after their accident, patients in whom an arterial blood gas measurement was not obtained at day 5, and patients who were treated with hypothermia were excluded, leaving 18 patients for review. Patients were divided into two groups according to time of fracture fixation: early fracture fixation (EFF), occurring within the first 24 hours after the patient's accident $(n=8)$, and late fracture fixation $(\mathrm{LFF})$, occurring after day 6 following the accident $(\mathrm{n}=$ 10). We compared $\mathrm{PaO}_{2} / \mathrm{FIO}_{2}$ ratio (P/F ratio) at days 1 and 5 between the two groups and within each group. No differences were found between groups in regard to age, Injury Severity Score, and head AIS and lower-extremity AIS. The average $\mathrm{P} / \mathrm{F}$ ratio of the EFF group was $453.3 \pm 56.6 \mathrm{mmHg}$ at day 1 and $405.9 \pm 52.7 \mathrm{mmHg}$ at day 5 . The average $\mathrm{P} / \mathrm{F}$ ratio of the $\mathrm{LFF}$ group was $408.4 \pm 71.9 \mathrm{mmHg}$ at day 1 and $305.1 \pm 104.6 \mathrm{mmHg}$ at day 5 . Although the difference in $\mathrm{P} / \mathrm{F}$ ratio between groups at day 1 was not statistically significant, the difference in $\mathrm{P} / \mathrm{F}$ ratio at day 5 was statistically significant $(\mathrm{p}<0.05)$. In addition, although there was no significant difference in $\mathrm{P} / \mathrm{F}$ ratio at days 1 and 5 in the EFF group, the difference in P/F ratio at days 1 and 5 in the LFF group was statistically significant $(\mathrm{p}<0.05)$. No deaths occurred in either group. We concluded that early fixation of lower-extremity long bone fractures in patients with severe head injury may prevent progressive oxygenation deterioration.

(JJAAM. 2010; 21: 19-28)

Keywords: femur fracture, tibia fracture, multiple trauma, pulmonary function, $\mathrm{PaO}_{2} / \mathrm{FIO}_{2}$

Received on August 27, 2009 (09-059) 